\title{
Feasibility analysis of traditional rice farming with combine harvester in Teureubeh Village, Aceh Besar District
}

\author{
Husaini*, Rizki Ardiansyah, Muhammad Ismail, and Rini Andriani \\ Aceh Assessment Institute Agriculture (BPTP) Aceh, 23125, Indonesia
}

\begin{abstract}
Traditional rice farming requires a lot of time and effort, therefore the high farming costs needed. The use of mechanization in rice farming is a technology can give the benefit to increase the farming efficiency and anticipate the scarcity of resources. This study aims to analyse the feasibility of lowland rice farming using agricultural machinery, both technical, financial and social feasibility. The research was conducted in Teureubeh Village, Jantho City District, Aceh Besar District. Primary data obtained from the survey results assisted by qualitative data obtained from observations. The results showed that technically a combine harvester could be operated to land conditions suitable, was more profitable than the traditional method, its showed from the value of $\mathrm{R} / \mathrm{C}(2.4)$, in the rice harvesting process has not had a negative impact on farmers, and has even provided benefits for farmers in harvest period due to the difficulty of labor available at the research location.
\end{abstract}

\section{Introduction}

The development mission of Indonesia under the Joko Widodo administration as stated in Nawacita is to point out and create the agricultural sector as a strategic space in increasing the standard of living of farmers. The nine ideals are indeed political in nature, but they compile the basis of the problems experienced by the Indonesian people and strategies to alleviate them [1]. One of the based points in this research is "developing Indonesia from the periphery" by strengthening the agricultural sector, which the majority of people depend on for their livelihoods.

Aceh Province is currently classified as a province that relies on the agricultural sector as the life support for the community, including Aceh Besar District, which is one of the centers for rice production in Aceh Province which accounts for 10 percent of total rice production at the provincial level [2]. In order to increase production, the several policies were implemented by the Aceh Besar government, such as recommending the use of agricultural machinery, especially at harvest season. This policy is in line with the mission of the Ministry of Agriculture to increase the rice production and farmers' income. In addition to increasing the efficiency and income of rice farming, the use of agricultural

\footnotetext{
* Corresponding author: hussainiyussuf85@gmail.com
} 
machinery (alsintan) at harvest time is very effective in overcoming the limited labor entering the main harvest $[3,4]$.

The farmers' adoption of harvest and post-harvest technology is still low, which results in relatively high rice yield losses [5]. According to [6], states that the shrinkage of harvest in irrigated rice fields is 13.35 percent higher than rainfed land (10.39 persent) and lower than in tidal fields (15.26 persent). The current post-harvest handling condition that occurs at the research location is the farmers are still conducting the traditional handling with simple technology. This is the reason why the production and income of farmers are still low. Therefore, to increase the harvest production and farm income, the farmers should use the innovation. One of the technologies for the farmers in order to prevents overcome crop losses is with using a combine harvester at harvest season. The using of combine harvester also to prevent as the solution in the scarcity of the workers in the big famer season.

This paper aimed to determine the feasibility of lowland rice farming that applies mechanization, especially from a technical, financial and social perspective. The assessment of these three aspects is very important in seeing the economic feasibility of farmers who apply agricultural machinery. This research is expected to be useful for farmers and policymakers as material for suggestions in the use of agricultural machinery in a sustainable manner in lowland rice farming.

\section{Methods}

This research was conducted in Teureubeh Village, Jantho Subdistrict, Aceh Besar District in May-August 2018. The selection of the research location was carried out by purposive sampling with consideration that the village was one of the villages that applied the agricultural mechanization system in rice farming, especially during planting and harvesting. The primary data as data source used in this research with using a case study approach with quantitative methods assisted by qualitative data through observation, and in-depth interviews with key informants, namely the Head of BPP, field agricultural extension (PPL), farmers who apply mechanization and traditional farmers as many as 16 people and 2 agricultural machine tool operators. The Qualitative methods are used in order to obtain descriptive data in the form of written words from the sample used as research respondents [7]. The two calculations used are income analysis and farming feasibility [8].

\subsection{Analysis of farming}

The Farming income is the total of farmer income reduced by the farm production costs within a certain period of time [9]. This study uses the income analysis at the farmer level, by the number of the value of lowland rice farming production within a certain period of time. The calculation of farmers' income from lowland rice farming uses with the following equation:

$$
\begin{aligned}
& \pi=T R-T C \\
& T R=Y \cdot P_{y} \\
& T C=F C+V C
\end{aligned}
$$

Explanation:

Income $(\boldsymbol{\pi})$, Total Revenue $(\boldsymbol{T R})$, Total Cost $(\boldsymbol{T C})$, Fixed Cost $(F C)$, Variabel Cost $(V C)$, Quantity $(Y)$, and Price $(P)$. 


\subsection{Feasibility of farming}

The Farming feasibility can be seen from the value of $\mathrm{R} / \mathrm{C}$ ratio and $\mathrm{B} / \mathrm{C}$ ratio. The $\mathrm{R} / \mathrm{C}$ ratio is calculated by the following equation:

$$
R / C \text { ratio }=\frac{T R}{T C}
$$

Explanation:

Total Revenue $(T R)$, Total Cost $(T C)$ with Criteria, R/C $>1$, The profitable farming (revenue is bigger than the cost) ; $\mathrm{R} / \mathrm{C}<1$, loss farming (costs bigger than revenue), and; $\mathrm{R} / \mathrm{C}=1$, farming paid off (revenue equals cost).

\section{Result and discussion}

\subsection{Technical feasibility}

The effort to provide permanent machine (combine harvester) is to reduce crop losses in the post-harvest process, with maintaining the quality of the harvest, maintaining the storage capacity and competitiveness of agricultural products, especially for the rice in the global market. The results showed that the use of a combine harvester could reduce crop loss by 4.61 percent [10]. According to [11], concluded that agricultural mechanization technology is very efficient in terms of labor, cost and time besides it can also reduce crop loss. The same case was found by [12] with using of a combine harvester harvesting machine can reduce crop loss by $2-4$ percent. This amount is better than manual harvesting (conducted by human), which is 7.89 percent [13].

The stages of crop loss mostly occur in conventional harvesting systems (using sickles) include the cutting process, during stacking, transportation and during threshing [10]. However, there are several technical obstacles that become the problem in how to use of a combine harvester, in special case if the land is muddy, the machines cannot work effectively and even often strike because of muddy. This case also founded by [14], that one of the technical factors that causes farmers to be reluctant to use the Combine Harvester is due to the condition of the rice fields which are muddy and sloppy or has swampy rice fields area. Therefore, the farmers prefer to use machines with large capacities so that they are easy to harvest (the corp machine is not easy to break down). This case also founded by [15], that each technology needs to adjust several things, including in terms of type, suitable with local conditions of society, agronomic aspects, socio-economic, and environmental conditions.

In general, the area of rice fields in Teureubeh Village, Jantho City District isideal for harvesting using a combine harvester, with an average land area of $1800 \mathrm{~m} 2-2500 \mathrm{~m} 2$ [16]. Therefore, using of these tools is relatively suitable and effective. In addition, the use of a combine harvester can decide several stages of work because of the mobility and the capability of machine is equipped with a cutting machine, a thresher, and can package grain in one work process. This eliminates the need for farmers to incur panicle collection (heaping) costs and threshing costs. 
Table 1. Harvest area, production and rice productivity in Aceh Besar

\begin{tabular}{|l|r|r|r|r|r|}
\hline \multirow{2}{*}{\multicolumn{1}{|c|}{ Description }} & \multicolumn{5}{|c|}{ Years } \\
\cline { 2 - 6 } & $\mathbf{2 0 1 3}$ & $\mathbf{2 0 1 4}$ & $\mathbf{2 0 1 5}$ & \multicolumn{1}{c|}{$\mathbf{2 0 1 6}$} & \multicolumn{1}{c|}{$\mathbf{2 0 1 7}$} \\
\hline Harvest Area (000 ha) & 36.209 & 38.429 & 47.277 & 41.193 & 48.108 \\
\hline Production (ton) & 243.734 & 264.190 & 310.477 & 258.969 & 305.167 \\
\hline Productivity (ton/ha) & 6,73 & 6,87 & 6,57 & 6,29 & 6,34 \\
\hline
\end{tabular}

\subsection{Financial feasibility}

The evolution of technology always has advantages for human and makes work easier for users, including of the agricultural machine tools for the farmers. The emergence of a combine harvester is one of the advantages of technology in facilitating the work of farmers when they enter the harvest season. According to [17], farmers are actually very rational in determining technology choices in increasing their production. obviously, technology adoption is takes time for the farmers to use and familiar with it, so there are often pro and contra in society regarding the acceptance of this tool. Besides the many advantages that are obtained, the presence of a new technology will have negative effects, such as shifting the use of human job in rural areas to machines.

This study examined the aspects of using tools and machines in farming management, that is farming with the application of mechanization and non-mechanization. The difference between the two are in the wetland rice harvesting process, where the mechanized farming system uses a combine harvester machine and the non-mechanized farming system uses human labor during the harvesting process. The difference in lowland rice farming management affects the income obtained by farmers (Table 2), seen in the components of costs incurred and farm income.

The Production costs incurred by farmers in conducting rice field area consist of fixed costs (land rent and rice zakat) and variable costs (seeds, fertilizers, pesticides and labor / combine harvester). The production cost of non-mechanized lowland rice farming system $(17,820,000$ IDR $)$ is higher than the mechanized farming system $(14,840,000$ IDR). The difference in the value of this production cost lies in the post-harvest expenses, namely the costs incurred to pay for the worker in the process of harvesting rice field area. The amount of costs incurred is influenced by the amount of the worker in harvest conduct and the number of days spent in the harvesting process.

The harvest cost using a combine harvester is 3,000,000 IDR, less than that for using the worker, which is amount 6,000,000 IDR. The application of a combine harvester can save on harvesting costs and increase farmers' income compared to using the worker. With the use of a combine harvester in the harvesting process, it is hoped that farmers in Jantho District will not experience difficulties in getting labor in harvesting lowland rice as they often experience. 
Table 2. The Analysis of mechanized and traditional of rice farming in Teureubeh Village, Jantho City District (ha/section)

\begin{tabular}{|r|l|r|r|}
\hline \multirow{2}{*}{ No } & \multicolumn{1}{|c|}{ Description } & \multicolumn{2}{c|}{ Value (IDR) } \\
\cline { 3 - 4 } & & \multicolumn{1}{c|}{ Mechahnized } & \multicolumn{1}{c|}{ Traditional } \\
\hline 1. & Profit & 35.250 .000 & 35.000 .000 \\
\hline & Quantity (kg) & 7.500 & 7.000 \\
\hline & Price (IDR/kg) & 4.700 & 5.000 \\
\hline 2. & Cost of Production & 16.180 .000 & 19.160 .000 \\
\hline & A. Fixed Cost & 6.580 .000 & 6.580 .000 \\
\hline & B. Variabel Cost & 9.600 .000 & 12.580 .000 \\
\hline 3. & Revenue (IDR/ha) & 19.070 .000 & 15.840 .000 \\
\hline 4. & R/C ratio & 2,18 & 1,83 \\
\hline
\end{tabular}

The income of rice farming using mechanization is 23 percent bigger than nonmechanization, this result influenced by the amount of use of seeds, harvest costs, harvest yields and the selling price of harvested dry unhulled rice (GKP). The selling price of GKP in the non-mechanized system is higher than the mechanized system. The results caused by using the combine harvester in permanent process, it cannot reduce the waste water of the grain because there is no drying process in the combine harvester. In addition, grain that has been harvested with a combine harvester tends to have a higher level of dirtiness, which has an impact on the selling price of GKP. According to [18], the harvesting process in the mechanization system can prevent potential losses from loss of production received by farmers.

The rice yield loss rate in Indonesia is quite high, amounting to 20.42 percent, of which 9.5 percent occurs during the harvesting process. Table 2 shows that the selling price of GKP using a combine harvester (mechanized) is lower than the price of GKP using labor (non-mechanized), with a price difference 300-500 IDR/kg. Farmers who use a combine harvester generate a higher income 19,070,000 IDR/ha/seasion compared to farmers who use human or non-mechanized labor $(15,840,000 \mathrm{IDR} / \mathrm{ha} /$ seasion). The total of revenue received by the farmer depend on total cost the revnue total and expense cost by the farmer.

The value of $\mathrm{R} / \mathrm{C}$ ratio with using of mechanization (2.18) and non-mechanization (1.83), it shows the farm revenue and income with mechanization is bigger than that of nonmechanization. The results of research by [3], the income obtained from rice combinetechnology is relatively larger than conventional. The use of the combine harvester can increase the value of the $\mathrm{R} / \mathrm{C}$ ratio by 2.18 , where for each expenditure $1,000 \mathrm{IDR}$, the income generated is 2,180 IDR by using the combine harvester. These results indicate that the two farming systems are feasible to apply.

\subsection{Social feasibility}

In general, the agricultural sector, especially for the food crops (rice) is classified as the largest employer of labor in Indonesia, reaching 44 - 55 percent or a total of 16.3 million people in 2013, although this condition continues to decline due to the conversion of agricultural land to the other sector [19]. According to [11], mentioned the negative impact of using agricultural mechanization can shift the pattern of employment opportunities for rural farm workers and reduce the wages of farm laborers in the Bawon system.

Swatika [5] mentioned the presence of harvesting machine technology among rural communities has also affected by the pressure from harvest workers for fear of losing their jobs. In addition, the agricultural mechanization will dissolve the norms and the dependence that has occurred in rural areas, could be decrease the status of the role of women [20]. 
Nevertheless, the results of a study conducted in Teureubeh Village, Jantho District, Aceh Besar indicated that the presence of agricultural machinery, especially the combine harvester, was very beneficial for the farmers (Table 3). The use of mechanization in harvesting activities is more efficient in terms of labor, cost and time. The same thing was conveyed by [11] that the use of agricultural machine tools in the post-harvest process can benefit farmers both in terms of time and cost. This condition is also based on the worker (labor) is not available at the location, especially at harvest season, it must be imported from outside the sub-district such as Seulimuem District.

Table 3. The Percentage of farmers, total area and percentage of farmers' land ownership in Teureubeh Village, Jantho City District, Aceh Besar District, 2018.

\begin{tabular}{|r|l|r|r|}
\hline \multirow{2}{*}{ No } & \multicolumn{1}{|c|}{ Description } & \multicolumn{2}{c|}{ Land Owner Status (Ha) } \\
\cline { 3 - 4 } & & \multicolumn{1}{c|}{ Owner } & Rented (farmer) \\
\hline 1 & Respondent (\%) & 61 & 39 \\
\hline 2 & Authorization Land Area (m) & 155.000 & 106.000 \\
\hline 3 & Percentage of Authorization Area (\%) & 59 & 41 \\
\hline 4 & The Average of Farmer Authorization land Area (m) & 7.381 & 7.571 \\
\hline
\end{tabular}

The cost of paying workers from outside the village is classified as higher because of the additional transportation costs compared to workers from inside the village. Therefore, the presence of harvesting machine technology in the Teureubeh village location is socially very feasible to facilitate and speed up the harvest process for local farmers.

The harvest system using of rice harvesting tools with mechanization (Combine Harvester) is an effort to anticipate labor shortages in the field at harvest time [21]. However, it was found in several areas that the presence of harvesting machines caused social inequality for the workforce community (especially for the female farmers) which had been the mainstay of the village community when the harvest season arrived $[22,11]$. Therefore, to convince the rural farmers to use alsintan, is need the role of assistant for socizlization process to change the farmer's mindset in order to accept mechanization-based technology. According to [23] stated one of the determining factors for the adoption of agricultural mechanization in farmers is due to the intensity of the extension carried out by field officers.

In Teureubeh village, rice cultivation is dominated by female farmers, while harvesting activities are carried out by women and men. According to [24], cited the presence of agricultural machine tools, especially planting machines affected the social changes in social structures in community life, especially for agricultural laborers. However, this condition occurred at the different location research in the planting stage they were still doing it manually using human (worker).

\section{Conclusion}

In conclusion, based on the results and discussion from this research, the summarize as mention below:

1. Technically, the utilization of of agricultural machinery (combine harvester) can be implemented in Jantho District, Aceh Besar. However, it is necessary concerning to the several aspects such as engine capacity and land conditions where the machine is used for dry land area.

2. For the financial side point, using the combine harvesteris very convenience and comparing to the traditional system, it shows from the amount of the value $\mathrm{R} / \mathrm{C}(2,18)$. 
3. The last stage from the social aspect, using the combine harvesterin harvest process showing there is no negative effect for the farmers, instead of give the convinenience and beneficially from the difficult to hire the workers in big harvest season.

\section{References}

1. M. Soleman., M. Noer., Politik. 13, 1 (2017).

2. Badan Pusat Statistik. Jumlah Desa di Provinsi Aceh Menurut Klasifikasi dan Kabupaten/Kota (2016).

3. Maksudi I. Efektivitas Penggunaan Mesin Panen (Combine Harvester) Pada Pemanenan Padi di Kabupaten Pidie Jaya. Skripsi, (2016).

4. Husaini. Dilema Regenerasi Petani. Majalah Sinar Tani Edisi Khusus Pekan Nasional (Penas) Kelompok Tani Nelayan Andalan (KTNA) Provinsi Aceh (2017).

5. Swastika DKS. Teknologi Panen dan Pascapanen Padi: Kendala Adopsi dan Kebijakan Strategi Pengembangan. (Pusat Sosial Ekonomi dan Kebijakan Pertanian, 2012).

6. Nugraha, S., Buletin Teknologi Pascananen Pertanian. 8, 1 (2012).

7. Bungin, B. Penelitian Kualitatif: Komunikasi, Ekonomi, Kebijakan Pubik, dan Ilmu Sosial Lainnya. (Jakarta, Prenada Media Group, 2011).

8. Soekartawi. Ilmu Usahatani dan Penelitian untuk Pengembangan Petani Kecil. (Jakarta, Universitas Indonesia Press, 2011).

9. Gittinger, JP. Analisa Ekonomi Proyek-Proyek Pertanian. (UI-Press., Jakarta, 2008).

10. Pondan VT., Lengkey LCChE., Ludong D. Kajian Kehilangan Hasil Pada Pemanenan Padi Sawah Menggunakan Mesin Mini Combine Harvester Maxxi-M. (Studi Kasus di Desa Torout Kecamatan Tompaso Baru Kabupaten Minahasa Selatan). Program Teknik Pertanian Fakultas Pertanian, Universitas Sam Ratulangi. https://ejournal.unsrat.ac.id/index.php/cocos/article/view/13898 (2016).

11. Purwantini TB., Susilowati SH., Analisis Kebijakan Pertanian. 16, 1 (2018).

12. Hindiyani, L. Studi Kapasitas Kerja dan Susut Pemanenan Rice Combine Harvester di Desa Sukamandi, Subang, Jawa Barat. Departemen Teknik Mesin dan Biosistem. Fakultas Teknologi Pertanian. IPB. Bogor (2013).

13. Ikhsan, M. Studi Kapasitas Kerja dan Susut Saat Panen Padi (Oryza sativa L.) Varietas Ciherang Menggunakan Paddy Mower. Departemen Teknik Mesin dan Biosistem. Fakultas Teknologi Pertanian. IPB. Bogor (2014).

14. Siadina, Kandatong, Astuti I., Agrovital : Jurnal Ilmu Pertanian. 4, 1 (2019).

15. Hegazy R., Schmidley A., Bautista E., Sumunistrado D., Gummert M., Elepaño A. Mechanization in Rice Farming-Lessons Learned from Other Countries. Asia Rice Foundation. (2013).

16. Balai Penyuluhan Pertanian Kota Jantho. Laporan Tahunan Kegiatan Balai Penyuluhan Pertanian Kecamatan Kota Jantho (2018).

17. Popkin S. The Rational Peasant: The Political Economy of Rural Society in Vietnam (1979).

18. Balai Besar Penelitian Pasca Panen Pertanian. Penanganan Pasca Panen Padi. Balai Besar Penelitian Pasca Panen Pertanian (2011).

19. Pusat Data dan Sistem Informasi Pertanian. Statistik Lahan Pertanian Tahun 2012-2016 (2017).

20. Munthe, HM. Pengaruh Modernisasi Pertanian Terhadap Partisipasi Perempuan di Pedesaan: Suatu Tinjauan Sosiologi. Fakultas Ilmu Sosial dan Ilmu Politik. Jurusan Sosiologi. Universitas Sumatera Utara (2002).

21. Amirrullah J. Efisiensi Penggunaan Alat Mesin Panen Padi Combine Harvester Pada Lahan Sawah Pasang Surut di Kabupaten Banyuasin Sumatera Selatan. Balai 
Pengkajian Teknologi Pertanian Sumatera Selatan in Proceedings of Seminar Nasional Lahan Suboptimal 2016, Palembang 20-21 Oktober (2016).

22. Yasar, M. Modernisasi Pertanian Aceh (2017).

23. Ayandiji A, Olofinsao OT., IOSR Journal of Environmental Science, Toxicology and Food Technology (IOSR-JESTFT). 9, 3 (2015).

24. Sitompul, RS. Mekanisasi Pertanian dan Kemiskinan Pedesaan. Studi Tentang Penggunaan Traktor dan Status Sosial Ekonomi Buruh Tani di Dusun III Suka Maju, Sei Mencirim, Kabupaten Deli Serdang. Departemen Sosiologi Fakultas Ilmu Sosial dan Ilmu Politik Universitas Sumatera Utara (2013). 